\title{
The Impact of Jak1/Jak2 Inhibitor Ruxolitinib on the Spleen Size and Symptom Burden in Myeloproliferative Diseases
}

\author{
Sude H. AKTIMUR ${ }^{1}$, Umit Y. MALKAN ${ }^{2}$, Damla N. EYUPOGLU ${ }^{2}$, Ibrahim C. HAZNEDAROGLU ${ }^{2}$, \\ Engin KELKITLI' ${ }^{1}$, Hilmi M. ATAY ${ }^{1}$, Gursel GUNES ${ }^{2}$, Sezgin ETGUL ${ }^{2}$, Tuncay ASLAN ${ }^{2}$, \\ Hakan GOKER ${ }^{2}$, Nilgun SAYINALP², Salih AKSU², Osman I. OZCEBE ${ }^{2}$, \\ Yahya BUYUKASIK ${ }^{2}$, Mehmet TURGUT ${ }^{1}$ \\ ${ }^{1}$ Ondokuz Mayıs University, Faculty of Medicine, Division of Hematology, Samsun \\ ${ }^{2}$ Hacettepe University, Faculty of Medicine, Division of Hematology, Ankara, TURKEY
}

\begin{abstract}
Ruxolitinib as a JAK1 and JAK2 inhibitor drug has recently been approved for the treatment of patients with high- or intermediate-risk myelofibrosis with symptomatic splenomegaly. Clinical development of ruxolitinib has currently focused on the $\mathrm{Ph}^{\star}$ negative myeloproliferative neoplastic disorders (MPN). The aim of this study is to assess the impact of ruxolitinib treatment on the clinical course of $\mathrm{Ph}^{\star}$ negative myeloproliferative disorders. Forty-three patients who were under ruxolitinib treatment and followed-up between years 1987-2015 in Hacettepe University Medical School Hematology Clinic and Ondokuz Mayis University Hematology Clinic with myeloproliferative disease without Philadephia chromosome translocation were retrospectively analyzed. The constitutional symptoms were decreased in $97 \%$ of patients after ruxolitinib treatment. The mean spleen sizes before and after ruxolitinib treatment were $229 \pm 35$ versus $202 \pm 31 \mathrm{~mm}$, respectively $(p<0.001)$. In this study, we observed a reduction in spleen size after ruxolitinib treatment in Turkish patients with MPN and this reduction was statistically significant. Moreover, nearly all of the MPN patients' constitutional symptoms were improved. Those observations are concordant with other geographical MPN data obtained from different countries. Further experimental and clinical studies into the efficacy and safety of ruxolitinib in patients with MPN are necessary to elucidate its role in special subgroups of MPN patients, such as patients undergoing hematopoietic stem cell transplantation and the patients with vascular disorders such as hepatoportal thrombosis.
\end{abstract}

Keywords: Ruxolitinib, Spleen size, Symptom burden, Myeloproliferative diseases

\section{ÖZET}

Myeloproliferatif Hastalıklarda Jak1/Jak2 İnhibitörü Ruksolitinib'in Dalak Boyutu ve Hastalık Semptomları Üzerindeki Etkisi

Ruksolitinib, semptomatik splenomegalisi olan orta ve yüksek riskli myelofibrosis hastalarının tedavisinde kullanımı onaylanmış bir JAK1 ve JAK2 inhibitörüdür. Ruksolitinibin günümüzdeki klinik gelişimi Ph* negatif miyeloproliferatif neoplastik hastallılar (MNH) üzerine odaklanmışır. Bu çalışmanın amacı, ruksolitinib tedavisinin $\mathrm{Ph}^{*}$ negative MNH'ın klinik seyri üzerindeki etkisini araştırmaktır. Ruksolitinib tedavisi alan ve Hacettepe Üniversitesi Tıp Fakültesi Hematoloji Kliniği ve Ondokuz Mayıs Üniversitesi Hematoloji Kliniği'nde 19872015 yılları arasında takip edilen toplam 43 filadelfiya kromozom translokasyonu negatif miyeloproliferatif neoplazi hastası geriye dönük olarak analiz edilmiştir. Hastaların \%97'sinde ruksolitinib tedavisi sonrası konstitüsyonel semptomlarda azalma saptanmıştır. Ruksolitinib tedavisi öncesi ve sonrası ortalama dalak boyutu, sırasıyla 229 \pm 35 mm’ye karşı 202 \pm 31 mm olarak saptanmıştır $(p<0.001)$. Biz bu çalışmada, ruksolitinib tedavisi alan miyeloproliferatif neoplazi hastalarında dalak boyutlarında istatistiksel olarak anlamlı bir küçülme saptadık. Ayrıca, çalışmaya katılan hastaların tamamına yakınında konsitusyonel semptomlarda ruksolitinib tedavisi sonrası azalma saptandı. Bu veriler farklı ülkelerde ve coğrafi bölgelerde yapılmış olan diğer araştırmalarla uyumludur. Hematopoietik kök hücre nakli ve hepatoportal tromboz gibi myeloproliferatif hastalıkların alt gruplarında, ruksolitinibin etkinlik ve güvenilirliğini araştırmayı hedefleyen klinik ve deneysel çalışmaların gelecekte yapılmasına ihtiyaç vardır.

Anahtar Kelimeler: Ruksolitinib, Dalak boyutu, Konstitusyonel semptomlar, Miyeloproliferatif hastalıklar 


\section{INTRODUCTION}

The Janus kinase 2 (JAK2) mutations are detected nearly all of the polycytemia vera (PV) cases and nearly half of the essential trombocytosis or primary myelofibrosis cases. ${ }^{1}$ JAK2 is a gene found on the short arm of chromosome 9 and it is related with the hypersensitivity of progenitor cells to growth factors in myeloproliferative neoplasia (MPN). JAK1 and JAK2 induced signal transducer and activators of transcription (STATs) leads to the modification of gene expression. Ruxolitinib is a Janus kinase inhibitor which inhibits the dysregulated JAK signaling. ${ }^{2-4}$

Ruxolitinib as a JAK1 and JAK2 inhibitor drug has recently been approved for the treatment of patients with high- or intermediate-risk myelofibrosis (MF) with symptomatic splenomegaly. ${ }^{5}$ This approval in MF depends upon two different phase 3 randomized clinical trials (RCT) namely COMFORT-I and COMFORT-II. ${ }^{6,7}$ COMFORT-I compared ruxolitinib with placebo in 309 patients with MF, whereas COMFORT-II compared the drug with the best-available therapy (mostly hydroxyurea) in $219 \mathrm{MF}$ patients. Both of the RCTs attained the primary endpoint of $>35 \%$ reduction in spleen size, as measured by imaging techniques, at the 24 or 48 weeks of the ruxolitinib treatment initiations. ${ }^{8-10}$ Clinical development of ruxolitinib has currently focused on the $\mathrm{Ph}^{*}$ negative myeloproliferative neoplastic disorders.

The aim of this study is to assess the impact of ruxolitinib treatment on the clinical course of $\mathrm{Ph}^{*}$ negative myeloproliferative disorders. The need of pharmacobiological assessments in addition to the risk profile for ruxolitinib in MPN is required in different patient populations Worldwide.

\section{PATIENTS AND METHODS}

All patients who were under ruxolitinib treatment and followed-up between years 1987-2015 in Hacettepe University Medical School Hematology Clinic and Ondokuz Mayis University Hematology Clinic with myeloproliferative disease without Philadephia chromosome translocation were retrospectively analyzed. There were a total of 43 patients. 25 patients were followed-up in Ondokuz Mayis University Hematology Clinic, whereas 18 patients were followed-up in Hacettepe University Medical School Hematology Clinic. All of the ethical considerations were strictly handled in accordance with the Helsinki Declaration. Patients' age of diagnosis, gender, constitutional symptoms, spleen size before and after ruxolitinib treatment and other clinical parameters were noted. All of the Ruxolitinib drugs have been obtained from the official compassionate use program approved by the Turkish health authorities (T.C. Ilac Eczacilık Genel Mudurlugu). Retrospective evaluation of the patient report forms were performed within the file archives of Samsun 19 Mayis University Medical School and Hacettepe University Medical School Hematology Departments.

\section{Statistical Analysis}

Statistical Packages for the Social Sciences v20.0 (SPSS Inc., Chicago, Ill., USA) software was used for statistical analyses. Data were given as median (minimum-maximum). Bivariate correlation analysis for categorical and continuous data was performed by Spearman's and Pearson's correlation analysis. A p value below 0.05 was considered as statistically significant.

\section{RESULTS}

There were total 43 patients with MPN. Types of MPN among the patients were polycythemia Vera, essential thrombocytosis, myelofibrosis and overlap syndromes in 13, 7, 21 and 2 patients, respectively. The main demographic parameters of participants were given in Table 1. There was no family history of myeloproliferative diseases among participants. Hepatomegaly was detected in $90 \%$ of the patients whereas pruritus was present only $47 \%$ of the patients. Minor neurological and constitutional symptoms were observed in $48 \%$ and $90 \%$ of the patients, respectively. There was thrombosis and bleeding history before diagnosis in $11 \%$ and $8 \%$ of the patients, respectively. Sites of thrombosis before diagnosis were, portal vein thrombosis, deep vein thrombosis, cerebrovascular event in $50 \%, 25 \%, 25 \%$ of patients, respectively. Sites of bleeding episodes before diagnosis were epistaxis, gingival hemorrhage in $64 \%$ and $36 \%$ patients, respectively. Antiplatelet, androgen and 


\begin{tabular}{|c|c|}
\hline Parameter & Data \\
\hline Age & $61(37-79)$ \\
\hline Gender (F/M) & $16 / 27$ \\
\hline Spleen size before ruxolitinib(mm) & $224(158-307)$ \\
\hline Cardiovascular risk (Y/N)(\%) & $32 / 68$ \\
\hline White blood cell $\left(x 10^{3} / \mu l\right)$ & $12.3(2.7-55.5)$ \\
\hline Platelet $\left(\times 10^{3} / \mu \mathrm{l}\right)$ & $385(42-1920)$ \\
\hline Hemoglobin (g/dl) & $10(7-21)$ \\
\hline LDH elevation (Y/N)(\%) & $87 / 13$ \\
\hline Presence of mutation analysis $(\mathrm{Y} / \mathrm{N})(\%)$ & $95 / 5$ \\
\hline JAK-2 mutation (Y/N/borderline)(\%) & $63 / 35 / 2$ \\
\hline MPL mutation $(\mathrm{Y} / \mathrm{N})(\%)$ & $22 / 78$ \\
\hline Secondary myelofibrosis (Y/N)(\%) & $37 / 63$ \\
\hline Red blood cell transfusion history (Y/N)(\%) & $50 / 50$ \\
\hline Y: Yes; N: No & \\
\hline
\end{tabular}

steroid treatments were present in 91\%, 39\% and $12 \%$ patients, respectively. No patients had history of erythrocyte stimulating agent treatment. Splenectomy was performed only in $6 \%$ of the patients. Only two patients had concomitant cancer history. These were cholangiocellular in one patient and gastric cancer in the other patient. Only in one patient, the blast count in bone marrow aspiration was higher than 5\%. Leukemic transformation was observed in only one patient. No patients were undergone hematopoietic stem cell transplantation. Conventional cytogenetic analysis was applied in 6 patients. 4 patients had normal karyotype and 2 patients had complex karyotype. 6 patients were lost. Exitus reasons were pneumonia in 2 patients, myocardial infarction, acute respiratory distress syndrome, sepsis and cholangiocellular carcinoma in each other patients. The treatment data were given in Table 2. All patients had first line cytoreduc-
Table 3. Ruxolitinib treatment details of the studied patients with myeloproliferative diseases

\begin{tabular}{|ll|}
\hline Treatment details & Data \\
\hline Ruxolitinib dosage $(\mathrm{mg})$ & $40(10-80)$ \\
$\begin{array}{l}\text { Duration of ruxolitinib (months) } \\
\text { Improvement of constitutional symptoms }\end{array}$ & $14(1-34)$ \\
$\quad$ after ruxolitinib (Y/N) (\%) & $97 / 3$ \\
Spleen size after ruxolitinib treatment (mm) & $201(140-270)$ \\
\hline
\end{tabular}

tive treatment. Anagrelide was not used as first line treatment agent in our patients. $37 \%$ of patients had second line treatment. Hydroxycarbamide was not used as second line treatment agent in our patients. Only one patient had third line treatment and interferon was given to this patient for 15 months. Ruxolitinib treatment details were given in Table $3.55 \%$ of patients were using ruxolitinib with dosage of $40 \mathrm{mg}$. Ruxolitinib was solely used in 64\% patients. In $23 \%$ patients it was used with hydroxycarbamide, $7 \%$ with hydroxycarbamide +interferon, $3 \%$ with anagrelide, $3 \%$ with hydroxycarbamide + anagrelide. The mean spleen sizes before and after ruxolitinib treatment were $229 \pm 35 \mathrm{~mm}$ versus $202 \pm 31$, respectively ( $\mathrm{p}$ value $<0.001$ ).

\section{DISCUSSION}

In this study, we observed a reduction in spleen size after ruxolitinib treatment in Turkish patients with MPN and this reduction was statistically significant. Moreover, nearly all of the MPN patients' constitutional symptoms were improved. Those observations are concordant with other geographical MPN data obtained from different countries such as Taiwan ${ }^{11}$, Japan ${ }^{12}$, Korea ${ }^{13}$, Denmark ${ }^{14}$, Finland ${ }^{15}$, Israel ${ }^{16}$, United States ${ }^{17}$ and other parts of the World ${ }^{18}$.

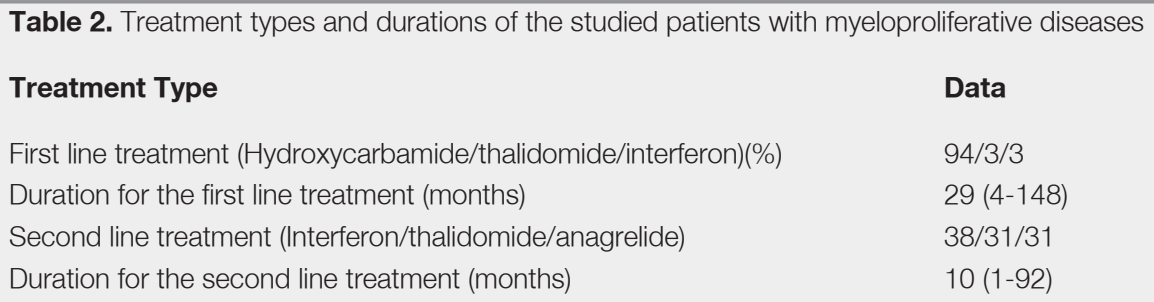


Ruxolitinib is a "JAK-STAT signaling pathway inhibitor" targeted drug with predictable pharmacobiological actions. ${ }^{19}$ The main function of JAKSTAT signaling pathway is cellular proliferation in health and disease. Ruxolitinib should, thus, be considered as an "anti-proliferative" medicine. ${ }^{2}$ Therefore ruxolitinib has the potential to inhibit neoplastic cellular proliferation of MPN and can cause cytopenias due to its "anti-proliferative" effects at any hematopoietic lineage. Current view of ruxolitinib in MPN is dependent upon mainly the disease risk profile of the given MPN entity. ${ }^{20}$ However, this risk-only approach is not sufficient and can cause mechanistic, wrong way of decision that ruxolitinib is unnecessary in low-risk MPN at all. Likewise, ruxolitinib may be considered as ineffective, useless, harmful, dangerous in (very) high-risk advanced/terminal MPN due to cytopenias of the drug itself. Ruxolitinib could precipitate anemia, leukopenia, and thrombocytopenia in an already pancytopenic patient with MPN. ${ }^{2}$ However, there are some initial clues that ruxolitinib can reverse bone marrow fibrosis in MPN if the patient population (such as hyperproliferative bone marrow with splenomegaly and peripheral cytosis) is carefully selected and long-time exposure to the drug (such as 48 months) would be possible..$^{21,22}$ Bone marrow microenvironment may be modulated via ruxolitinib in MPN. ${ }^{23}$ Ruxolitinib is also an effective treatment for CALR-positive patients with myelofibrosis. ${ }^{24}$

We have previously proposed that the ideal MPN population that ruxolitinib shall be administered; i.e; hyperproliferative bone marrow with or without fibrosis and peripheral cytosis and organomegaly. ${ }^{2}$ MPN disease risk categories of the specific MPN patient populations shall be detected as well as the established Ruxolitinib effects (decreased spleen size, symptom burden). Our present data supported this notion and future trials could be designed to test those hypotheses. Angona and coworkers searched the effects of ruxolitinib on hematopoietic stem cells (HSCs, CD34+ CD38), hematopoietic progenitor cells (HPCs, CD34+ $\mathrm{CD} 38+)$ and granulocytes from the patients with JAK2V617F(+) myeloproliferative neoplasms. ${ }^{25}$ They indicated that ruxolitinib had clinical benefit in terms of reduction of the spleen size in spite of a minimal effect on the JAK2 V617F mutant allele burden of HSCs and HPCs. ${ }^{25}$ Therefore the impact of ruxolitinib on the spleen size and symptom burden in MPN is not restricted with the positivity of JAK2 mutations as of our present MPN patient group. Based on the results of Phase III clinical studies, ruxolitinib provided rapid and durable improvement of myelofibrosis-related splenomegaly and symptoms irrespective of mutation status, and was associated with a survival advantage compared with placebo or best available therapy. ${ }^{8,26}$

The treatment with ruxolitinib alleviates symptom burden and improves quality of life of patients with advanced MPN also without clinically significant splenomegaly. ${ }^{27}$ We have also observed symptomatic relief in our patient cohort without enormously enlarged spleen in the present study. The positive effect of ruxolitinib on patient symptoms is not related to reduction of spleen size. On the other hand, hemoglobin changes on ruxolitinib treatment may not be the same prognostic implications as hemoglobin changes that occur as a consequence of myelofibrosis progression. Therefore transient hemoglobin changes during ruxolitinib therapy should not lead to premature interruption or discontinuation. ${ }^{28}$ The same logic shall be applied to thrombocytopenia. ${ }^{29} \mathrm{We}$ observed the positive impact of ruxolitinib on the spleen size and symptom burden in our cytopenic MPN patient group as well.

Further experimental and clinical studies into the efficacy and safety of ruxolitinib in patients with MPN are necessary to elucidate its role in special subgroups of MPN patients, such as patients undergoing hematopoietic stem cell transplantation ${ }^{30-32}$ and the patients with vascular disorders such as hepatoportal thrombosis.

\section{Conflict of Interest Statement}

The authors of this paper have no conflicts of interest, including specific financial interests, relationships and/ or affiliations relevant to the subject matter or materials included. 


\section{REFERENCES}

1. Vannucchi AM, Guglielmelli P, Tefferi A. Advances in understanding and management of myeloproliferative neoplasms. CA Cancer J Clin. 59: 171-191, 2009.

2. Eliacik E, Isik A, Aksu S, Uner A, Buyukasik Y, Sayinalp N, et al. Pharmacobiological Approach for the Clinical Development of Ruxolitinib in Myeloproliferative Neoplasms. Turk J Haematol. 32: 163-167, 2015.

3. Chase A, Bryant C, Score J, Haferlach C, Grossmann V, Schwaab J, et al. Ruxolitinib as potential targeted therapy for patients with JAK2 rearrangements. Haematologica. 98: 404408, 2013

4. Deininger M, Radich J, Burn TC, Huber R, Paranagama D, Verstovsek S. The effect of long-term ruxolitinib treatment on JAK2p.V617F allele burden in patients with myelofibrosis. Blood. 126: 1551-1554, 2015.

5. Verstovsek S. Ruxolitinib: the first agent approved for myelofibrosis. Clin Adv Hematol Oncol 10: 111-113, 2012

6. Verstovsek S, Mesa RA, Gotlib J, Levy RS, Gupta V, DiPersio $\mathrm{JF}$, et al. A double-blind, placebo-controlled trial of ruxolitinib for myelofibrosis. N Engl J Med. 366: 799-807, 2012.

7. Harrison C, Kiladjian JJ, Al-Ali HK, Gisslinger H, Waltzman R, Stalbovskaya $\mathrm{V}$, et al. JAK inhibition with ruxolitinib versus best available therapy for myelofibrosis. N Engl J Med. 366:787798, 2012

8. Cervantes F, Vannucchi AM, Kiladjian JJ, Al-Ali HK, Sirulnik A, Stalbovskaya V, et al. Three-year efficacy, safety, and survival findings from COMFORT-II, a phase 3 study comparing ruxolitinib with best available therapy for myelofibrosis. Blood. 122: 4047-4053, 2013

9. Verstovsek S, Mesa RA, Gotlib J, Levy RS, Gupta V, DiPersio $J F$, et al. Efficacy, safety and survival with ruxolitinib in patients with myelofibrosis: results of a median 2-year follow-up of COMFORT-I. Haematologica. 98: 1865-1871, 2013.

10. Verstovsek S, Mesa RA, Gotlib J, Levy RS, Gupta V, DiPersio JF, et al. Efficacy, safety, and survival with ruxolitinib in patients with myelofibrosis: results of a median 3-year follow-up of COMFORT-I. Haematologica. 100: 479-488, 2015.

11. Chen YY, Huang CE, Lee KD, Chen CC. Clinical efficacy and safety of ruxolitinib in the management of myelofibrosis: A single institution experience in Taiwan. Hematology. 21: 3-9, 2016.

12. Oritani K, Okamoto S, Tauchi T, Saito S, Ohishi K, Handa H, et al. A multinational, open-label, phase 2 study of ruxolitinib in Asian patients with myelofibrosis: Japanese subset analysis. Int J Hematol. 101: 295-304, 2015.

13. Jung CW, Shih LY, Xiao Z, Jie J, Hou HA, Du X, et al. Efficacy and safety of ruxolitinib in Asian patients with myelofibrosis. Leuk Lymphoma. 56: 2067-2074, 2015.

14. Bjorn ME, Holmstrom MO, Hasselbalch HC. Ruxolitinib is manageable in patients with myelofibrosis and severe thrombocytopenia: a report on 12 Danish patients. Leuk Lymphoma. 57: 125-128, 2016.

15. Hahl J, Kurki S, Miettinen T, Snicker K. Cost-Effectiveness of Ruxolitinib for The Treatment of Myelofibrosis In Finland.
Economic Evaluation Based on Finnish Auria Biobank Data on Health Care Resource Utilization. Value Health. 18: A669, 2015.

16. Ellis MH, Lavi N, Mishchenko E, Dally N, Lavie D, Courevitch A, et al. Ruxolitinib treatment for myelofibrosis: Efficacy and tolerability in routine practice. Leuk Res. 39: 1154-1158, 2015.

17. Geyer H, Cannon K, Knight E, Fauble V, Camoriano J, Emanuel $\mathrm{R}$, et al. Ruxolitinib in clinical practice for therapy of myelofibrosis: single USA center experience following Food and Drug Administration approval. Leuk Lymphoma. 55: 195-197, 2014.

18. Davis KL, Cote I, Kaye JA, Mendelson E, Gao H, Perez Ronco J. Real-World Assessment of Clinical Outcomes in Patients with Lower-Risk Myelofibrosis Receiving Treatment with Ruxolitinib. Adv Hematol. 2015: 848473, 2015.

19. Ho PJ, Marlton P, Tam C, Stevenson W, Ritchie D, Bird R, et al. Practical management of myelofibrosis with ruxolitinib. Intern Med J. 45: 1221-1230, 2015.

20. Haznedaroglu IC. Ruxolitinib for myelofibrosis. N Engl J Med. 366: 2032, 2012

21. Breccia M, Molica M, Colafigli G, Alimena G. Improvement of bone marrow fibrosis with ruxolitinib: will this finding change our perception of the drug? Expert Rev Hematol. 8: 387-389, 2015.

22. Wilkins BS, Radia D, Woodley C, Farhi SE, Keohane C, Harrison $\mathrm{CN}$. Resolution of bone marrow fibrosis in a patient receiving JAK1/JAK2 inhibitor treatment with ruxolitinib. Haematologica. 98: 1872-1876, 2013.

23. Caocci G, Maccioni A, Murgia F, Perra A, Usai M, Piga M, et al. Modulation of bone marrow microenvironment following ruxolitinib therapy in myelofibrosis. Leuk Lymphoma. 2015: 1-4 2015.

24. Guglielmelli P, Rotunno G, Bogani C, et al. Ruxolitinib is an effective treatment for CALR-positive patients with myelofibrosis. Br J Haematol. 173: 938-940, 2016.

25. Angona A, Alvarez-Larran A, Bellosillo B, Longaron R, Fernandez-Rodriguez C, Besses C. Dynamics of JAK2 V617F allele burden of CD34(+) haematopoietic progenitor cells in patients treated with ruxolitinib. Br J Haematol. 172: 639-642, 2016.

26. Arana Yi C, Tam CS, Verstovsek S. Efficacy and safety of ruxolitinib in the treatment of patients with myelofibrosis. Future Oncol. 11: 719-733, 2015.

27. Benjamini O, Jain P, Estrov Z, Kantarjian HM, Verstovsek S Therapeutic effects of ruxolitinib in patients with myelofibrosis without clinically significant splenomegaly. Blood. 120: 27682769, 2012.

28. Al-Ali HK, Stalbovskaya V, Gopalakrishna P, Perez-Ronco J, Foltz L. Impact of ruxolitinib treatment on the hemoglobin dynamics and the negative prognosis of anemia in patients with myelofibrosis. Leuk Lymphoma. 2016: 1-4, 2016.

29. Talpaz M, Paquette R, Afrin L, Hamburg SI, Prchal JT, Jamieson $\mathrm{K}$, et al. Interim analysis of safety and efficacy of ruxolitinib in patients with myelofibrosis and low platelet counts. J Hematol Oncol. 6: 81, 2013. 
International Journal of Hematology and Oncology

30. Hanif A, Hari PN, Atallah E, Carlson KS, Pasquini MC, Michaelis LC. Safety of ruxolitinib therapy prior to allogeneic hematopoietic stem-cell transplantation for myeloproliferative neoplasms. Bone Marrow Transplant. 51: 617-618, 2016.

31. Jaekel N, Behre G, Behning A, Wickenhauser C, Lange T, Niederwieser D, et al. Allogeneic hematopoietic cell transplantation for myelofibrosis in patients pretreated with the JAK1 and JAK2 inhibitor ruxolitinib. Bone Marrow Transplant. 49: 179-184, 2014.

32. Stubig T, Alchalby H, Ditschkowski M, Wolf D, Wulf G, Zabelina $T$, et al. JAK inhibition with ruxolitinib as pretreatment for allogeneic stem cell transplantation in primary or post-ET/PV myelofibrosis. Leukemia. 28: 1736-1738, 2014.

\section{Correspondence}

Dr. Mehmet TURGUT

Ondokuz Mayis Üniversitesi

Tip Fakültesi

Hematoloji Anabilim Dali

Samsun, TURKEY

Tel: (+90-362) 3121919

e-mail: turgutm@omu.edu.tr 